\title{
Research as Community-Building \\ Perspectives on the scholarship of engagement
}

Gateways: International Journal of Community Research and Engagement Vol 8/No 1 (2015): 139-49 (C) UTSePress and the author

ISSN 1836-3393

\section{Barry Checkoway}

University of Michigan

If research were a form of community-building, what would it be? What is a community-building approach to research, compared to one that is designed primarily to study a subject for its own sake? Community-building is a process which builds community. Research is a process which develops knowledge. Research can be viewed as community-building, but this approach is not normal, and there is relatively little written about the topic.

I am a community worker and university professor who practises 'research as community-building', that is, 'research' and 'community-building' as interrelated parts of the same process.

In this article, I examine my approach to research as a form of community-building. I draw upon a program in metropolitan Detroit that I am involved with, as well as tell something of my own story, in the hope that these reflections might be useful to others who are considering work of this type.

\section{RECONCEIVING RESEARCH}

Community-building is a process which builds community. It has core concepts, such as 'starting with people', which refers to the idea that the process should originate in the experience of people; 'strengthening the community' as a unit of solution; 'joining together', in which individuals accomplish more together than any one of them could if acting alone; and 'planning and organising', as a means for community members to accomplish their goals (Checkoway 1997).

Community-building can have various outcomes. For example, it can contribute to an individual's competencies and connectedness; to organisational capacity and leadership development; and to better housing, healthier neighbourhoods and other community-level effects. There also are factors that can contribute to successful practice, such as identifiable leadership, widespread participation, working relationships, and group cohesion and cooperation in agreeing upon solutions to problems (DeFilippis \& Saegert 2012; Mattesich \& Monsey 2001; Sampson 2012). 
Research is a process for developing knowledge. Researchers formulate theories, gather information, confirm facts and solve problems about which they care. They synthesise existing studies, explain why things happen the way they do, or interpret the significance of findings for further thought and action (Babbie 2012; Neuman 2006).

Research has many methodologies. Researchers can gather information through qualitative methods such as observations, interviews, focus groups, or surveys; or quantitative methods, which produce numerical and statistical explanations: correlation and regression analysis to determine the relationship between two or more variables; experimental research, which places participants in experimental and control groups; or meta-analysis, which draws upon several existing studies. There is no single best methodology; there are many (Bryman 2012).

Research as community-building is imaginable in most academic disciplines and professional fields, such as psychology, sociology, social work and public health, and there is nothing a priori to prevent any researcher, such as a philosopher or physicist, from work that builds community in every stage of the process. The issue is neither the discipline nor the field, but rather how research is practised, and this partly depends on whether the researcher is up to the challenge.

This article examines 'research as community-building' and draws upon a project in which I am deeply involved, emphasising three stages of the research process: (1) defining the problem; (2) gathering the information; and (3) using the findings. These are not the only research stages, but are among the important ones. First, however, I will discuss the way in which my research approach derives from both personal and professional experiences. Understanding my methodology means understanding me.

\section{MY OWN APPROACH}

I grew up in Newburyport, Massachusetts, a small city north of Boston. The city is picturesque, from its farms and commons to cobblestone streets and wharves on the river, through to marsh and the ocean. It was home to fishing and shipbuilding in revolutionary times, and cotton mills and shoe factories during the industrial period.

Newburyport was known for its social stratification. It was studied by W Lloyd Warner and a team of Harvard anthropologists, and published as the 'Yankee City' series (1942, 1945, 1947, 1959, 1975), in which he identified three social classes: upper, middle and lower, with each level further divided into upper and lower. Upper-class Yankees lived in stately houses on High Street, middle and lower middle-class families on Middle Street, and lower-class residents confined themselves to Low Street and the river road.

Newburyport was, as the novelist John P Marquand (1949) wrote, a place of class and tradition on a river by the sea dominated by 'old money' families who built factories and 
financial institutions, and where 'everything is in its place and there's a place for everything'. He criticised Warner and other social scientists for their tendency to make generalisations about people based solely on their academic training or socialisation. They saw only what they had been trained to see.

I too have been socialised into the academy, but not before I was affected by my experience in the community. My family were Eastern European immigrants. My grandfather started as a ragpicker and later became a small businessman who helped other immigrants to settle in town. My father was a merchant and small businessman, and my mother was the daughter of a shoemaker and factory worker. We were religious minorities and attended $a$ traditional Jewish synagogue of 40 families in a city dominated by Yankees and Christians. My parents were aware that they were minorities in a society that was not theirs, and this affected their beliefs and behaviours.

Growing up, I easily grasped the nuances of small town New England life, the people and how they came together into a social structure. I was a regular at school board and city council meetings, and developed close relationships with the superintendent and mayor, both of whom lived down the street and taught me to believe that community change was possible and that I had the power to create it.

School was my base of operations. I was a hard worker, top student and class president - quite possibly the first ethnic person to be elected as such. School was the means for me to excel in the classroom and the community, and the two - school and community - were intertwined in my experience. For example, when a school board member forced the superintendent to resign, I took up a citywide petition, gathered thousands of signatures and convinced him to continue his role, silencing the board member who then was defeated for re-election.

At Wesleyan University, first, and then later as a doctoral student at the University of Pennsylvania, I continued my practice of combining campus and community work. My doctoral studies focused on community change, an approach that was reinforced by my professors. I helped establish an undergraduate program which enabled students to apply academic knowledge to realworld problem-solving through internships in community agencies of low-income neighbourhoods. This program reinforced my combination of research, learning and teaching, in which one relates to the other, all the while building community.

This pattern has continued in a succession of faculty positions: at the University of California, University of Illinois, and now at the University of Michigan. At Illinois, for example, my courses enabled students to collaborate with low-income community members in Chicago and St Louis neighbourhoods and established a community-based organisation that has continued for more than 40 years. At Michigan, we collaborate with community partners in rural areas, small towns, and suburbs 
and neighbourhoods of metropolitan Detroit in Michigan, and in the South Bronx, Boston, Detroit, Chicago, Mississippi Delta, Appalachia, Albuquerque, East Oakland, and other areas.

Overall, my role as a community organiser is inseparable from my role as a university professor. While actively engaged in the community, I also present papers at professional meetings and publish articles which draw upon my research, in a continuous mutually reinforcing process in which 'doing' stimulates 'knowing' and vice-versa.

My expertise derives from my own experience. I am aware that others' derives from theirs, and I believe that there is nothing a priori that makes one person's experience better than another's.

Following is an example of how my approach plays out in practice.

\section{YOUTH DIALOGUES IN METROPOLITAN DETROIT}

Metropolitan Detroit is highly segregated, with small areas of diversity. The city is largely black, and the suburbs mostly white, although some suburbs are increasing in populations of African, Asian, Middle Eastern and Latin American descent.

Segregation increases inequalities in metropolitan Detroit. For example, some schools have high-quality resources and facilities, whereas others have outdated books and plumbing so old that toilet paper is rationed. In schools which are becoming more diverse, achievement gaps and intergroup incidents are increasing, and teachers lack training in how to handle such incidents (Darden \& Kamel 2000; Farley, Danziger \& Harry 2002; Gallagher 2010; Kenyon 2004; LeDuff 2013; Sugrue 2005).

Young people in metropolitan Detroit want to communicate with others who are different from themselves, but segregation limits them. They want to address discrimination, but segregation prevents them from forming the relationships needed for collective action. They realise the benefits of diversity, but are not organised in a way that would allow them to strengthen these benefits (Young, n.d.).

Youth Dialogues on Race and Ethnicity in Metropolitan Detroit is a program which was established to increase dialogue among young people - of African, Asian, white European, Middle Eastern and Latin American descent - in the neighbourhoods and suburbs. The program includes intergroup dialogues, metropolitan tours, residential retreats, community projects and youth leadership. It runs educational and training workshops and policy summits, involving youth leaders and adult allies. Research and evaluation are integral to the program (Checkoway 2009; Checkoway \& Richards-Schuster, 2011).

\section{Defining the Problem}

\section{What is the problem to be solved? Why is it important, and to whom?}

Defining the problem is a research stage which determines everything else, for if researchers or community members define 
situations as real, they are real in their consequences. When segregation is defined by urban planners as a problem caused by white flight to the suburbs, for example, the subsequent work will differ from when it is defined as caused by the investment decisions of bankers and builders. It is not whether there is a correct definition; it is that the definition of the problem affects the action (Merton 1968; Watanabe 2009).

The youth dialogues program originated when a community leader wanted to address the social isolation of young people in metropolitan Detroit and approached me about how to proceed. We convened community meetings with representatives of racial and ethnic groups, which established face-to-face relationships and produced a proposal that was funded by both a community-based foundation and the University of Michigan.

We were conscious of 'defining the problem' by starting with 'community participation', 'group formation' and 'relationship building', which would contribute to subsequent program implementation. We talk with our community partners in face-toface meetings about what we want to accomplish and form groups designed to accomplish the purpose. When community members define their own problems, it engages them in the process.

In comparison, there is a professor down the hall at my university who himself defines research problems that he thinks are important, based upon his personal or professional interests. He generally gets his ideas when he sits in his office, visualises a project that builds upon earlier work, reads an article that is provocative, or talks with colleagues on the campus. Then, he reviews the literature which relates to his idea; formulates questions whose answers are measureable; collects data using standardised methods; and analyses the findings in terms of his original objectives. In so doing, he is highly conscious of a 'community of experts' who care a great deal about his problem definition. He says that he never involves 'laypersons' in this work, except as 'human subjects' (Booth, Papaioannou \& Sutton 2012).

\section{Gathering the Information}

\section{What do we want to learn? How can information be gathered in ways which develop knowledge and contribute to community- building?}

Professionals gather information as a normal part of their practice, such as when lawyers take depositions to determine which facts are relevant, or physicians review laboratory tests before diagnosis and treatment (Gänshirt 2007; Schön 1983).

In the youth dialogues program, youth-adult research teams were formed, with members selected for their involvement in the community, not for their technical expertise. Their community involvement was their expertise; tailored workshops prepared them for their research roles.

The research teams gathered information through a variety of qualitative and quantitative methods. For example, they gathered information about family histories, social identities, and 
similarities and differences among group members. They examined the forces that shaped their thinking, stereotypes they have heard and prejudices they have learned from the 'cycle of socialization' (Harro 2013). School was another point of information gathering and awareness raising: the school's racial and ethnic composition, its curricular content and institutional practices. In the neighbourhoods and suburbs, a bus tour let team members observe schools and malls, industrialisation and deindustrialiation, development and decline, and discrimination and civil rights. The tour included visiting a concrete wall constructed by builders to separate whites from blacks. A public gallery later held an exhibition of their photographs, which was open to all community members.

Team members asked researchers to create pre- and post-test questionnaires to assess attitude changes in the program, using a Multigroup Ethnic Identity Measure and Color-Blind Racial Attitudes and Collective Self-Esteem Scales. With assistance, they later analysed quantitative data and other findings about the program in which they were participants.

In comparison, my colleague employs linear models, factor analysis, multidimensional scaling and other research methods. He belongs to a centre that provides cutting-edge study design, data collection, data processing services, and access to the world's largest archive of digital data.

In gathering information, my colleague refers to himself as a 'detached' expert who defines problems in 'dispassionate' ways and who gathers data on 'human subjects' through 'value free' methods that assure the 'validity', 'reliability' and 'generalizability' of the findings. When he gathers information in accordance with these criteria, he believes that he is doing his job.

When I work in collaboration with our community partners in accordance with both 'research' and 'community' principles, I believe that I am doing mine.

\section{Using the Findings}

How can findings be used to address a problem? If research is for a purpose, what will you do with what you learn?

In the youth dialogues program, dissemination is inseparable from research. Participants are active communicators. For example, we helped prepare a script based on their experiences with a youth theatre company that participated in the program. The result, Speak for yourself, has been performed in more than 100 school assemblies and community centres. Actors come to the front of the stage and facilitate 'talk backs', in which audience members stand and speak - often for the first time - about their experiences with discrimination and diversity (Checkoway n.d.). With input from a writing coach, participants have also published My dreams are not a secret: Teenagers in metropolitan Detroit speak out (Young n.d.), a book in which they write about finding their voice. As a result of the program, one participant created a youth dialogues course in her high school. She prepared a proposal for the school board, the 
superintendent assigned a teacher, and now students enrol in a permanent course, which, because of its success, was incorporated in a course required for all students. Other school districts have also established youth dialogues courses, resulting in more than 5000 students learning from the program.

Other participants formed the 'youth policy leaders' in order to address segregation and diversity. They gathered 3000 signatures and presented a resolution to the Michigan Board of Education for unanimous approval. The resolution calls for 'diversity learning for all students', 'teacher professional development' and 'student voice in policy decisions', and has been presented at conferences of youth leaders and school officials at the local, state and national levels.

When participants found that teachers were unprepared to facilitate sensitive discussions in the classroom, they asked school officials to offer professional development workshops with content on dialogue facilitation, role of teachers as change agents, and how to turn incidents into strategies. Teachers from more than 30 school districts have participated in these workshops and receive ongoing consultation and technical assistance, in partnership with the Intermediate School District in Michigan.

Participants write about their experiences. One young person wrote about her efforts to establish a course, another about her public policy experiences, and another an entire book about her involvement in the program. One adult wrote about how her school responded to news that an infamous racist was coming to demonstrate in front of the building, and another about her involvement in a 160-kilometre youth leadership march from Detroit to the State Capitol in Lansing in order to protest zerotolerance policies.

University partners participate in all of these dissemination efforts and, in addition, make presentations at professional meetings, publish articles in scholarly journals, and incorporate content into courses on campus and workshops in the community. For us, however, publications are only one form of dissemination.

In contrast, my colleague believes that the primary purpose of research is to understand a subject and views publications in scholarly journals as his dissemination. He cares what his peers think about his work and subscribes to a service which counts how many times they refer to him in their publications. He does not discuss the impact of his work on society, even when his funding comes from government agencies (Drake \& Jonson-Reid 2007).

\section{INSTITUTIONAL ISSUES}

I am a professor at the University of Michigan, an anchor institution with immense resources. It has centres, institutes, libraries, laboratories, housing and health services, arts and cultural programs, media networks, sports teams and conference facilities. It is more than a school; it is a major employer, provider and consumer of goods and services, and a powerful social 
and economic engine whose decisions have local, national and international effects.

Michigan has faculty members with expertise in a wide variety of academic disciplines and professional fields - including arts and sciences, architecture and urban planning, business, education, engineering, information, law, public health, public policy, social work and medicine - in which they conduct research, teach and train people, aggregate knowledge so as to make it more useful, and disseminate findings to popular and professional audiences.

Some faculty members are passionate about communitybuilding, incorporate this into their research and teaching, and receive recognition for their work.

Others have community interests but do not normally act upon them, or feel frustrated in their efforts to do so. My observation is that they have been conditioned to believe that community-building is a diversion from their real work and might even jeopardise their careers in the institution. They hear this from their dean, the provost reinforces it with a reward structure, the institutional culture perpetuates it, and they believe that it is true (Checkoway 2013).

It is ironic that this is the case. Studies show that faculty members who engage in community agencies have more publications in peer-reviewed journals, more funded research projects and higher student evaluations of their teaching than those who do not (Doberneck, Glass \& Schweitzer 2010; Patton \& Marver 1979).

Indeed, there are growing calls for change on a number of fronts: rewarding multiple forms of scholarship (Ellison \& Eatman 2008; O'Meara 2011; O'Meara \& Rice 2005), reframing incentives and rewards (Martinez-Brawley 2003; O'Meara \& Rice 2005), preparing future faculty (O'Meara 2010), reconsidering the roles of academic administrators (Langseth, Plater \& Dillon 2004), making the case for engaged scholarship (Foster 2010; Lynton 1995), moving faculty culture from private to public (Kecskes 2006) and creating institutional change (Fitzgerald, Burack \& Seifer 2011). Yet, despite all this evidence to the contrary, most faculty hold to beliefs and behaviours that were part of their conditioning.

When faculty members draw upon their expertise in community-building as an integral part of their role, they should be rewarded. I am aware that there are obstacles to research as community-building in the academy and understand the frustrations it causes to some of my colleagues. Certainly, any strategy to involve the faculty in community-building should have an appropriate reward structure, without which it is dysfunctional for the individual and for the institution. But, I assume that obstacles to change are a normal part of the change process and in fact can be a productive source of intellectual tension. 


\section{CONCLUSION}

If research were a form of community-building, what would it be? Our research on the Youth Dialogues on Race and Ethnicity in Metropolitan Detroit program shows that the program enables young people to develop knowledge of their racial and ethnic identities and those of others; to build awareness of race and racism as forces in their lives; and to take specific actions against racism in their own lives.

Our approach is that 'defining the problem' involves community members in group formation and leadership development. 'Gathering the information' enables them to ask questions about society and develop relationships for addressing them. 'Using the findings' results in theatre performances, youthauthored publications, permanent courses in schools and a youth leadership group whose members have produced tangible accomplishments.

Community-building is what I do, and research is instrumental to the work. I chose a career in higher education because of my belief that this would help facilitate a process in which higher education and community are intertwined, an approach which I first adopted when I was growing up and continued over the long haul. In this way, my personal and have professional roles are interrelated, and my hope is that this article might be useful to others who are interested in this approach.

\section{REFERENCES}

Babbie, E 2012, The practice of social research, Cengage Learning, Independence, $\mathrm{KY}$.

Booth, A, Papaioannou, D \& Sutton, A 2012, Systematic approaches to a successful literature review, Sage, Thousand Oaks, CA.

Bryman, A 2012, Social research methods, 4th edn, Oxford University Press, New York.

Checkoway, B 1997, 'Core concepts of community change', Journal of Community Practice, vol. 4, no. 1, pp. 11-29.

Checkoway, B 2009, 'Youth civic engagement for dialogue and diversity at the metropolitan level', The Foundation Review, vol. 1, issue 2, pp. 41-50.

Checkoway, B 2013, 'Strengthening the scholarship of engagement in higher education', Journal of Higher Education Outreach and Engagement, vol. 17, no. 4, pp. 7-21.

Checkoway, B (n.d.), Speak for yourself: Study guide, Youth Dialogues on Race and Ethnicity in Metropolitan Detroit, Ann Arbor, MI.

Checkoway, B \& Richards-Schuster, K 2011, 'Youth participation in community research for racial justice', in P Nyden, ed., Public sociology: Research, action, and change, Pine Forge Press, Newbury Park, CA.

Darden, J \& Kamel, S 2000, 'Black residential segregation in the city and suburbs of Detroit: Does socioeconomic status matter?', Journal of Urban Affairs, vol. 22, issue 1, pp. 1-13. 
DeFilippis, J \& Saegert, S (eds) 2012, The community development reader, Routledge, New York.

Doberneck, D, Glass, C \& Schweitzer, J 2010, 'From rhetoric to reality: A typology of publicly engaged scholarship', Journal of Higher Education Outreach and Engagement, vol. 14, no. 4, pp. 5-35.

Drake, B \& Jonson-Reid, M 2007, Social work research methods: From conceptualization to dissemination, Pearson, New York.

Ellison, J \& Eatman, T 2008, 'Scholarship in public: Knowledge creation and tenure policy in the engaged university', Imagining America, Syracuse, NY.

Farley, R, Danziger, S \& Harry J 2002, Detroit divided, Russell Sage Foundation, New York.

Fitzgerald, H, Burack, C \& Seifer, S 2011, Handbook of engaged scholarship: Vol. 1 Institutional change, Michigan State University Press, Lansing, MI.

Foster, K 2010, 'Taking a stand: Community-engaged scholarship on the tenure track', Journal of Community Engagement and Scholarship, vol. 3, no. 2, pp. 20-30.

Gallagher, J 2010, Reimagining Detroit: Opportunities for redefining an American city, Wayne State University Press, Detroit, MI.

Gänshirt, C 2007, Tools for ideas: Introduction to architectural design, Birkhäuser, Boston, MA.

Harro, B 2013, 'Cycle of socialization', in M Adams, W Blumenfeld, C Castaneda, H Hackman, M Peters \& X Zuniga (eds), Readings for diversity and social justice, 3rd edn, Routledge, New York.

Kecskes, K (ed.) 2006, Engaging departments: Moving faculty culture from private to public, individual to collective focus for the common good, Anker, Boston, MA.

Kenyon, A 2004, Dreaming suburbia: Detroit and the production of postwar space and culture, Wayne State University Press, Detroit, MI.

LeDuff, C 2013, Detroit: An American autopsy, Penguin Press, New York.

Langseth, M, Plater, W \& Dillon, S 2004, Public work and the academy: An academic administrator's guide to civic engagement and service learning, Anker, Bolton, MA.

Lynton, E 1995, Making the case for professional service, Americans Association for Higher Education, Washington, DC.

Marquand, J 1949, Point of no return, Little Brown \& Company, New York.

Martinez-Brawley, E 2003, 'The scholarship of engagement in a research university: Faculty incentives and disincentives', Metropolitan Universities Journal: An International Forum, vol. 14, pp. 116-30.

Mattesich, P \& Monsey, B 2001, Community building: What makes it work? A review of factors influencing successful community building, Amherst J Wilder Foundation, St Paul, MN.

Merton, R 1968, Social theory and social structure, rev. edn, Free Press, New York.

Neuman W 2006, Social research methods: Qualitative and quantitative approaches. Allyn \& Bacon, New York. 
O'Meara, KA 2010, 'Rewarding multiple forms of scholarship: Promotion and tenure', in H Fitzgerald, C Burack \& S Seifer (eds), Handbook of engaged scholarship: Contemporary landscapes, future directions, Vol. 1. Institutional change, Michigan State University Press, East Lansing, MI., pp. 271-94.

O'Meara, KA 2011, 'Faculty civic engagement: New training, assumptions, and markets needed for the engaged American scholar', in J Saltmarsh \& M Hartley (eds), To serve a larger purpose: Engagement for democracy and the transformation of higher education, Temple University Press, Philadelphia, PA, pp. 177-98.

O’Meara, K \& Rice, R 2005, Faculty priorities reconsidered: Rewarding multiple forms of scholarship, Jossey-Bass, San Francisco, CA.

Patton, C \& Marver, J 1979, 'Paid consulting by American academics, Educational Record, vol. 60, no. 2, pp. 175-84.

Sampson, R 2012, 'What community supplies', in J DeFilippis \& S Saegert (eds), The Community Development Reader, Routledge, New York, pp. 163-73.

Schön, D 1983, The reflective practitioner: How professionals think in action. Basic Books, New York.

Sugrue, T 2005, The origins of the urban crisis: Race and inequality in postwar Detroit, Princeton University Press, Princeton, NJ.

Warner, W 1959, The living and the dead: A study of the symbolic life of Americans. Yale University Press, New Haven, CT.

Warner, W 1975, Yankee city, Yale University Press, New Haven, CT.

Warner, W \& Low, J 1947, The social system of the modern factory, Yale University Press, New Haven, CT.

Warner, W \& Lunt, P 1942, The status system of a modern community, Yale University Press, New Haven, CT.

Warner, W \& Srole, L 1945, The social systems of American ethnic groups, Yale University Press, New Haven, CT.

Watanabe, K 2009, Problem solving 101: A simple book for smart people, Penguin, London.

Young, A (n.d.), My dreams are not a secret: Teenagers in metropolitan Detroit speak out, New Generation Press, Providence, RI. 